\title{
Estimation of variance components and prediction of breeding values in rubber tree breeding using the REML/BLUP procedure
}

\author{
Renata Capistrano Moreira Furlani ${ }^{1}$, Mario Luiz Teixeira de Moraes ${ }^{1}$, Marcos Deon Vilela de Resende ${ }^{2}$, \\ Enes Furlani Junior ${ }^{1}$, Paulo de Souza Gonçalves ${ }^{3}$, Walter Veriano Valério Filho ${ }^{1}$ \\ and João Rodrigues de Paiva ${ }^{4}$ \\ ${ }^{1}$ Universidade Estadual Paulista 'Júlio de Mesquita Filho', Faculdade de Engenharia de Ilha Solteira, \\ Ilha Solteira, SP, Brazil. \\ ${ }^{2}$ Rothamsted Research, Biomathematics and Statistics Department, England. \\ ${ }^{3}$ Instituto Agronômico, Campinas, SP, Brazil. \\ ${ }^{4}$ Empresa Brasileira de Pesquisa Agropecuária, CNPAT, Fortaleza, CE, Brazil.
}

\begin{abstract}
The present paper deals with estimation of variance components, prediction of breeding values and selection in a population of rubber tree [Hevea brasiliensis (Willd. ex Adr. de Juss.) Müell.-Arg.] from Rio Branco, State of Acre, Brazil. The REML/BLUP (restricted maximum likelihood/best linear unbiased prediction) procedure was applied. For this purpose, 37 rubber tree families were obtained and assessed in a randomized complete block design, with three unbalanced replications. The field trial was carried out at the Experimental Station of UNESP, located in Selvíria, State of Mato Grosso do Sul, Brazil. The quantitative traits evaluated were: girth (G), bark thickness (BT), number of latex vessel rings (NR), and plant height $(\mathrm{PH})$. Given the unbalanced condition of the progeny test, the REML/BLUP procedure was used for estimation. The narrow-sense individual heritability estimates were 0.43 for $\mathrm{G}, 0.18$ for $\mathrm{BT}$, 0.01 for NR, and 0.51 for $\mathrm{PH}$. Two selection strategies were adopted: one short-term (ST - selection intensity of $8.85 \%$ ) and the other long-term ( $L T$ - selection intensity of $26.56 \%$ ). For $\mathrm{G}$, the estimated genetic gains in relation to the population average were $26.80 \%$ and $17.94 \%$, respectively, according to the ST and LT strategies. The effective population sizes were 22.35 and 46.03 , respectively. The LT and ST strategies maintained $45.80 \%$ and $28.24 \%$, respectively, of the original genetic diversity represented in the progeny test. So, it can be inferred that this population has potential for both breeding and ex situ genetic conservation as a supplier of genetic material for advanced rubber tree breeding programs.
\end{abstract}

Key words: linear mixed model, effective population size, breeding strategies, rubber tree improvement.

Received: March 29, 2004; Accepted: November 11, 2004.

\section{Introduction}

The rubber tree belongs to the genus Hevea and the family Euphorbiaceae. Among the eleven species of the genus, the most important one is Hevea brasiliensis (Willd. ex Adr. de Juss.) Muell-Arg (George and Panikkar, 2000). It is currently planted in Asia as the main source of natural rubber, and in 2001 more than $64 \%$ of the world production came from Thailand (33\%), Indonesia (22\%) and India (9\%) (IRSG, 2004).

Historically, Brazil used to be the main world producer of natural rubber until the beginning of the twentieth

Send correspondence to Mario Luiz Teixeira de Moraes. Universidade Estadual Paulista 'Júlio de Mesquita Filho', Departamento de Fitotecnia, Tecnologia de Alimentos e Sócio-Economia, Faculdade de Engenharia de Ilha Solteira, Av. Brasil Centro 56, 15385 000 Ilha Solteira, SP, Brazil. E-mail: teixeira @agr.feis.unesp.br. century, but became an importer of this raw material in the $1950 \mathrm{~s}$. Although it is the birthplace of the species of this genus, in 2001 only $1.11 \%$ of the world production came from Brazil. Thus, two aspects have become important in rubber tree cultivation in Brazil: the search for better genetic material and the assessment of new methodologies.

The importance of the conservation and use of Hevea genetic resources was discussed by Ho (1979). This author recognized that in situ conservation is the best strategy for maintaining the forest genetic resources. However, such a strategy requires heavy investments and the conservation of genetic resources, such as the keeping of seed or plant material in gene banks. Paiva et al. (1994a, 1994b) reviewed the Brazilian rubber tree breeding program, analyzing its evolution in several states. For the Amazon region, a planting model was proposed which is believed will allow 
the simultaneous cultivation and genetic conservation of the rubber tree in its place of origin.

Nowadays, rubber tree breeding programs in Brazil are mainly conducted in the State of São Paulo. Results concerning genetic parameter estimates, genotype $\mathrm{x}$ environment interaction, mating system and genetic gain predictions were reported in a number of papers (Gonçalves et al., 1992, 2003; Boock et al., 1995; Costa et al., 2000b).

Precise estimation of variance components and accurate selection are of great importance in rubber tree breeding. They can be achieved through the use of optimal estimation/prediction procedures, which will lead to the maximization of genetic gain from selection. For unbalanced data sets in perennial plant species, the optimum estimation/prediction procedure is the REML/BLUP (restricted maximum likelihood/best linear unbiased prediction) (Resende et al., 1996). For balanced data sets, the estimation of variance components by the least squares method (analysis of variance) produces the same results as REML, and prediction of the genetic values by the multi-effect index method (Resende and Higa, 1994) is equivalent to individual BLUP, as demonstrated by Resende and Fernandes (1999).

This paper deals with the genetic analysis of a rubber tree progeny test established in a non-traditional cultivation area in the State of Mato Grosso do Sul. Its objectives were the estimation of variance components and the prediction of genetic values, with the purpose of starting a breeding and genetic conservation program in the region. The procedure applied was the REML/BLUP.

\section{Material and Methods}

\section{Location}

The trial was carried out at the Experimental Station of UNESP, located in Selvíria, State of Mato Grosso do Sul, Brazil, latitude $20^{\circ} 22^{\prime} \mathrm{S}$, longitude $51^{\circ} 22^{\prime} \mathrm{W}$, and average altitude of $335 \mathrm{~m}$. The climate of the region, according to the Köppen classification, is of the Aw type, defined as wet tropical, with a rainy season in the summer and a dry season in the winter, annual mean temperature of $24{ }^{\circ} \mathrm{C}$, mean annual rainfall of $1,232 \mathrm{~mm}$, and mean annual relative humidity of $64 \%$ (Hernandez et al., 1995). The soil in the area, according to the Brazilian Soil Classification System (Embrapa, 1999), is a clay type, Dystrophic Red Latosol, moderate, hypo-dystrophic, alic, lime, iron, compacted and very deep, moderately acid (Lvd).

\section{Material}

Rubber tree plants derived from open pollinated seeds collected in a natural population located in Rio Branco, AC, described by Paiva (1994a), were used in this study. The progeny test was set up in randomized complete blocks with 37 progenies (treatments) and three replications in an unbalanced form. The experimental plots were linear, with up to ten plants, in a spacing of $5 \times 3 \mathrm{~m}$.

Nine years after planting, the following quantitative traits were assessed: a) girth ( $\mathrm{G}$ in $\mathrm{cm})$; b) number of latex vessel rings (NR), determined by the Campinas Agronomic Institute (IAC); c) bark thickness (BT in mm); and d) plant height ( $\mathrm{PH}$ in $\mathrm{m})$.

\section{Statistic analysis}

\section{Mixed linear model}

According to Resende (2002a), the following mixed linear model is suitable to describe the data:

$$
y=X b+Z a+W c+e
$$

where $y$ : vector of data; $b$ : vector of fixed effects associated to block means; $a$ : vector of random additive genetic effects; $c$ : vector of random plot effects associated to environmental effects common to individuals in a plot; $e$ : vector of random errors and $X, Z$ and $W$ are incidence matrices, that associate the unknowns $b, a$ and $c$, respectively, to the data vector $y$.

\section{Distributions and structures of means and variances}

$$
\begin{aligned}
& y \mid b, V \sim N(X b, V) \\
& a \mid A, \sigma_{a}^{2} \sim N\left(0, A \sigma_{a}^{2}\right) \\
& c \mid \sigma_{c}^{2} \sim N\left(0, I \sigma_{c}^{2}\right) \\
& e \sigma_{e}^{2} \sim N\left(0, I \sigma_{e}^{2}\right) \\
& \operatorname{Cov}\left(a, c^{\prime}\right)=0 ; \operatorname{Cov}\left(a, e^{\prime}\right)=0 ; \operatorname{Cov}(c, e)=0 ; \\
& E=\left[\begin{array}{c}
y \\
a \\
c \\
e
\end{array}\right]=\left[\begin{array}{c}
X b \\
0 \\
0 \\
0
\end{array}\right] \text { and } \operatorname{Var}\left[\begin{array}{l}
y \\
a \\
c \\
e
\end{array}\right]=\left[\begin{array}{cccc}
V & Z G & W C & R \\
G Z & G & 0 & 0 \\
C W & 0 & C & 0 \\
R & 0 & 0 & R
\end{array}\right]
\end{aligned}
$$

where:

$$
\begin{aligned}
& G=A \sigma_{a}^{2} \\
& R=I \sigma_{c}^{2} \\
& C=I \sigma_{e}^{2} \\
& V=Z A \sigma_{a}^{2} Z^{\prime}+W I \sigma_{c}^{2} W^{\prime}+I \sigma_{e}^{2}=Z G Z^{\prime}+W C W^{\prime}+R
\end{aligned}
$$

The mixed model methodology permits the estimation of $b$ by the generalized least squares procedure and the prediction of $a$ and $c$ by the BLUP procedure. The following system of linear equations (called mixed model equations - MME) must be solved to obtain the solutions:

$$
\left[\begin{array}{l}
\hat{b} \\
\hat{a} \\
\hat{c}
\end{array}\right]=\left[\begin{array}{ccc}
X^{\prime} X & X^{\prime} Z & X^{\prime} W \\
Z^{\prime} X & Z^{\prime} Z+A^{-1} \lambda_{1} & Z^{\prime} W \\
W^{\prime} X & W^{\prime} Z & W^{\prime} W+I \lambda_{2}
\end{array}\right]^{-1}\left[\begin{array}{c}
X^{\prime} y \\
Z^{\prime} y \\
W^{\prime} y
\end{array}\right]
$$


where $\lambda_{1}=\frac{1-h^{2}-c^{2}}{h^{2}}=\frac{\sigma_{e}^{2}}{\sigma_{a}^{2}} ; \lambda_{2}=\frac{1-h^{2}-c^{2}}{c^{2}}=\frac{\sigma_{e}^{2}}{\sigma_{c}^{2}}$

$\lambda_{1}=\frac{\sigma_{e}^{2}}{\sigma_{a}^{2}} ; \lambda_{2}=\frac{\sigma_{e}^{2}}{\sigma_{c}^{2}}:$ shrinkage factors for random effects in the mixed model equations.

$A$ and $I$ : genetic additive relationship and identity matrices, respectively. The genetic relationship matrix was obtained by considering the open pollinated families as half-sib families. This is adequate for predominantly allogamous populations (Vencovsky and Barriga, 1992).

REML estimates of variance components were obtained via the expectation-maximization-EM algorithm (Dempster et al., 1977), according to the following expressions:

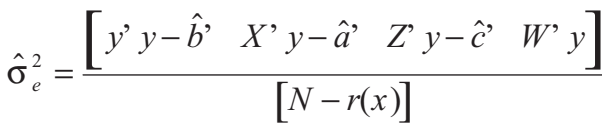

$$
\begin{aligned}
& \hat{\sigma}_{a}^{2}=\frac{\left[\begin{array}{ll}
\hat{a} A^{-1} & \hat{a}+\hat{\sigma}_{e}^{2} \operatorname{tr}\left(A^{-1} C^{22}\right)
\end{array}\right]}{q} \\
& \hat{\sigma}_{c}^{2}=\frac{\left[\hat{c}^{\prime} c+\hat{\sigma}_{e}^{2} \operatorname{tr} C^{33}\right]}{s}
\end{aligned}
$$

where $C^{22}$ and $C^{33}$ derive from:

$C^{-1}=\left[\begin{array}{lll}C_{11} & C_{12} & C_{13} \\ C_{21} & C_{22} & C_{23} \\ C_{31} & C_{32} & C_{33}\end{array}\right]^{-1}=\left[\begin{array}{lll}C^{11} & C^{12} & C^{13} \\ C^{21} & C^{22} & C^{23} \\ C^{31} & C^{32} & C^{33}\end{array}\right]=$ generalized inverse of the coefficient matrix of the MME; $t r$ : trace of a matrix; $r(x)$ : rank of the $X$ matrix; $N-r(x)$ : degrees of freedom for the error; $q$ : number of individuals; $s$ : number of plots and $N$ : total number of observations.

Narrow-sense individual heritability coefficients were estimated according to the expression:

$$
\hat{h}^{2}=\frac{\hat{\sigma}_{a}^{2}}{\hat{\sigma}_{a}^{2}+\hat{\sigma}_{c}^{2}+\hat{\sigma}_{e}^{2}}
$$

Standard deviations of the heritability coefficients were obtained from the information matrix of the mixed model equations.

The REML procedure of variance component estimation was developed by Patterson and Thompson (1971) and Thompson (1973). Details concerning this method were presented by Searle et al. (1992).

\section{Genetic gain prediction}

Estimation and prediction by the REML/BLUP procedure were performed using the Selegen-REML/BLUP software (Resende, 2002b).

The genetic gain $(\mathrm{G})$ was estimated as the mean of the genetic values of the selected individuals. Selection was practiced on the girth trait $(\mathrm{G})$, using individual predicted genetic values. Two strategies to estimate the genetic gain were adopted: 1) the long-term breeding strategy, with a selection intensity of $26.56 \%$, which is equivalent to the selection of one individual per progeny in each replication; and 2) the short-term breeding strategy, with a selection intensity of $8.85 \%$, that is equivalent to the selection of one plant per family in the whole test. The effective size $(\mathrm{Ne})$ was estimated by the expression:

$$
N_{e}=\frac{\left(4 N_{f} \bar{k}_{f}\right)}{\left[\bar{k}_{f}+3+\left(\frac{\sigma_{k f}^{2}}{\bar{k}_{f}}\right)\right]}
$$

where $\bar{k}_{f}=$ mean number of individuals selected per progeny; $\sigma_{k f}^{2}=$ variance of the number of individuals selected per progeny (Resende, 2002a).

The genetic diversity $(D)$ after selection can be quantified as proposed by Wei and Lindgren (1996) (in: Resende, 2002a): $D=N_{e f} / N_{f o}$, where $N_{f o}$ is the original number of progeny ( 37 in the present study); $N_{e f}$ is the effective number of selected progenies given by $N_{e}=\left(\sum k_{f}\right)^{2} / \sum k_{f}^{2}$. The $D$ estimates vary within the interval $0<D \leq 1$. A $D$ estimate close to 1 indicates that almost the total genetic variability of the reference population was maintained, whereas a $D$ estimate close to zero indicates that almost all the genetic variability contained in the original population was extinct.

\section{Results and Discussion}

Variance components and individual narrow-sense heritability estimates for the four traits are presented in Table 1 . The trait NR presented no genetic variation and consequently the estimated heritability was close to zero. The trait bark thickness showed a low heritability estimate (0.18), and the traits girth and plant height exhibited moderate heritability estimates ( 0.43 and 0.51 , respectively). These results demonstrate moderate possibilities for improvement of three out of the four traits evaluated. Such information is very useful for the starting of a rubber tree breeding program with this population in the State of Mato Grosso do Sul.

Table 1 - REML estimates of variance components and heritability for the traits girth (G), bark thickness (BT), number of latex vessel rings (NR) and plant height $(\mathrm{PH})$ in a nine-year-old rubber tree population established in Selvíria, MS, Brazil.

\begin{tabular}{lcccc}
\hline Traits & $\hat{\sigma}_{a}^{2}$ & $\hat{\sigma}_{c}^{2}$ & $\hat{\sigma}_{e}^{2}$ & $\hat{h}^{2}$ \\
\hline G (cm) & 75.6203 & 17.7701 & 80.9975 & $0.43 \pm 0.11$ \\
BT (mm) & 0.1107 & 0.0188 & 0.4785 & $0.18 \pm 0.07$ \\
NR & 0.0200 & 0.0905 & 2.6490 & $0.01 \pm 0.02$ \\
PH (m) & 2.0326 & 1.4273 & 0.5058 & $0.51 \pm 0.12$ \\
\hline
\end{tabular}

$\hat{\sigma}_{a}^{2}$ : additive genetic variance; $\hat{\sigma}_{c}^{2}$ : environmental variance among plots; $\hat{\sigma}_{e}^{2}$ : residual variance within plots; $\hat{h}^{2}$ : narrow-sense individual heritability. 
The economic product of a rubber tree is the latex. Latex yield is governed mainly by the genetic potential of the plant material. However, the expression of this genetic potential can be influenced by several other inherent traits of the tree, such as vigor (measured by girth) and bark thickness (Tan, 1987). Rubber breeders have therefore to consider these other traits. Moreover, the traits girth, bark thickness, plant height and latex vessel number are important aids in early selection, due to their association with latex yield. The early selection practice currently adopted in Malaysia consists of using yield and other traits such as $G$ and NR. Such traits are also used in planning crosses in that country (Tan, 1987). On the long run, it may be necessary to consider breeding rubber trees not only for their rubber yield, but also for wood as an additional product, to meet the shortage and demand of timber. The trait plant height is also important in this context. These facts reinforce the importance of the results obtained in this study, concerning genetic variability and heritability associated to the traits $\mathrm{G}$, $\mathrm{BT}$ and $\mathrm{PH}$.

Several authors have reported individual narrow-sense heritability estimates for the rubber tree. In general, their results have revealed that the genetic variation is largely accounted for by additive genetic variance (Valois et al., 1978; Paiva et al., 1982; Alika, 1985; Boock et al., 1995; Gonçalves et al., 1999, 2004; and Costa et al., 2000a and $b$ ). The results obtained in this study are in accordance with those.

The statistical procedure (REML) allowed to estimate the variance components in a situation of high unbalancing. This is an important feature in the context of the genetic improvement of native forest tree species. The establishment of balanced trials involving such species is usually problematic, due to the difficulties in seed collection, cutting production, and also due to the differential family survival. With the availability of the REML software, many unbalanced trials can now be analyzed, providing essential information for the design of efficient breeding programs.

Rubber tree improvement programs have been conducted in Brazil (Gonçalves et al., 1992, 1996, 1999, 2004; Costa, 2000a and b; Paiva, 1994a and b) and in many other countries, such as Malaysia, Indonesia, Thailand, India and Ivory Coast (Tan, 1987; Simmonds, 1989; Priyadarshan, 2003; Clément-Demange et al., 1995, 2000). The yield im- provement in rubber through breeding and selection has been spectacular. However, over the recent years, progress seems to have slowed down. Consequently, breeders have attempted to identify and formulate strategies to circumvent this. One of the problems identified was the narrow genetic base of the breeding populations. There have been four main approaches to broaden the genetic base: introduction or exchange of new genetic materials, germplasm conservation, evaluation and utilization of new genetic materials, and creating variability through mutation and induction of polyploidy. This paper deals with the second and third approaches.

Results concerning selection in the context of two breeding strategies are presented in Table 2.

The selection associated to the long-term breeding strategy provided an estimated genetic gain of $17.94 \%$, whereas the short-term breeding strategy led to a considerably higher estimated genetic gain of $26.80 \%$. However, the long-term breeding strategy can maintain $45.80 \%$ of the original diversity of the experimental population, against only $28.24 \%$ that can be maintained by the short-term strategy. The associated effective population sizes are 46 and 22 for the long-term and short-term breeding strategies, respectively. These results can justify the adoption of the two breeding strategies simultaneously, as a means to achieve higher genetic gains in the short-term and enough genetic variability in the long-term breeding program. Technical details concerning effective population size and selection limits were discussed by Falconer and Mackey (1996) and Vencovsky and Crossa (2003). In general, effective population sizes higher than 30 are sufficient for allowing genetic gain in the long term (Falconer and Mackey, 1996).

It can be said that the evaluated population presents potential for generating superior planting material. Such populations from the State of Acre were also introduced in several other countries and are believed to produce rubber of good quality (Tan, 1987).

Other current problems in rubber tree breeding are the long breeding and selection cycle and the inaccurate selection of parents for crossing. Rubber breeders require about 10 to 15 years to complete one breeding cycle and about 30 years to complete the selection cycle from hand pollination. This occurs because a period of 3 to 15 years of data recording is necessary to provide an accurate selection based on

Table 2 - Estimates of some genetic parameters for the girth trait in the short- (ST) and long- (LT) term breeding strategies of a nine-year-old rubber tree population in Selvíria,MS, Brazil.

\begin{tabular}{|c|c|c|c|c|c|c|c|c|c|c|}
\hline Breeding strategies & $N_{f}$ & $N$ & $\bar{k}_{f}$ & $\hat{\sigma}_{k f}^{2}$ & $\mathrm{p}(\%)$ & $G_{s}(\mathrm{~cm})$ & $G_{s}(\%)$ & $\bar{X}_{S}(\mathrm{~cm})$ & $D$ & $N_{e}$ \\
\hline ST & 16 & 37 & 2.31 & 3.03 & 8.85 & 10.73 & 26.80 & 50.76 & 0.2824 & 22.35 \\
\hline LT & 28 & 111 & 3.96 & 10.63 & 26.56 & 7.18 & 17.94 & 47.21 & 0.4580 & 46.03 \\
\hline $\bar{X}_{0}$ & $40.03 \mathrm{~cm}$ & & & & & & & & & \\
\hline
\end{tabular}

$N_{f}$ : number of selected families; $N$ : number of selected individuals; $G_{s}:$ genetic gain from selection; p: selection intensity; $\bar{X}_{0}:$ population mean; $X_{S}:$ mean of the improved population; $N_{e}$ : effective population size; $\bar{k}_{f}$ : mean number of selected individuals per family; $\hat{\sigma}_{k f}^{2}$ variance of the number of selected individuals per family; $D$ : genetic diversity. 
phenotypic means. The use of improved prediction methods such as BLUP provides higher selection accuracy and so permits to reduce drastically the recording period. Wise choice of parents for crossing is also desirable and critical. Such choice has traditionally been done using phenotypic estimates of the general combining ability (GCA). Gilbert et al. (1973) were the first ones to estimate GCA effects in rubber tree using an incomplete diallel model composed of unsystematic crosses (Gilbert, 1967). They showed that the lack of use of adequate analytical procedures in the past had failed to identify some potentially good crosses, which had been left out of the earlier programs. The BLUP procedure is an even better procedure, as it provides the predicted genetic values of the parents and then enables to make an accurate and wise choice of parents for crossing. This procedure is now being applied to rubber breeding in Brazil (Costa et al. 2002a and b). In the present study, the BLUP procedure permitted the identification of good potential parents within the families evaluated.

\section{Acknowledgements}

We thank FAPESP and CNPq for funding and Andréia Guerreiro, Alexandre Marques da Silva, Eduardo Gomes Rosa, John Kleber Morais Gomes, Márcio Rodrigues Barbosa, Selma Maria Bozzite de Moraes and Vanderley de Godoy Gonçalves for help in the field collections and handling of the samples in the laboratory. Renata Capistrano Moreira Furlani is recipient of FAPESP fellowship.

\section{References}

Alika JE (1985) Heritability and genotypic gain from selection in rubber (Hevea brasiliensis). Silv Genet 34:1-4.

Boock M, Gonçalves P de S, Bortoletto N and Martins ALM (1995) Herdabilidade, variabilidade genética e ganhos genéticos para produção e caracteres morfológicos em progênies jovens de seringueira. Pesq Agrop Bras 30:673-681.

Clément-Demange A, Rivano F, Nicolas D, Gnagne H and Legnaté H (1995) Stratégies de sélection chez l'hévéa. In: CIRAD (Montpellier), Traitements Statistiques des Essais de Sélection: Stratégies d'Amélioration des Plantes Pérennes (Actes du séminaire de biométrie et génétique quantitative), Montpellier, pp 227-242.

Clément-Demange A, Legnate H, Seguin M, Carron MP, Guen V, Chapuset T and Nicolas D (2000) Rubber tree. In: Charrier A, Jacquot M, Hamsons AD and Nicolas D (eds) Tropical Plant Breeding. CIRAD-ORSTOM, Montpellier, France, pp 455-480.

Costa RB da, Resende MDV de, Araújo AJ de, Gonçalves P de S and Silva MA (2000a) Maximization and genetic gain in rubber tree (Hevea) breeding with effective size restriction. Genet Mol Biol 23:457-462.

Costa RB, Resende MDV, Gonçalves, PS and Silva, MA (2002a) Individual multivariate REML/BLUP in the presence of genotype $\mathrm{x}$ environment interaction in rubber tree (Hevea) breeding. Crop Breed Appl Biot 1:131-140.
Costa RB, Resende MDV, Araújo AJ, Gonçalves PS and Higa AR (2000b) Selection and genetic gain in rubber tree (Hevea) populations using a mixed mating system. Genet and Mol Biol 23:671-679.

Costa RB, Resende MDV, Gonçalves PS, Arruda EJ and Oliveira LCS (2002b) Prediction of genotype values for yield trait in rubber tree clone test trial using REML/BLUP procedure. Crop Breed Appl Biot 2:575-582.

Dempster AP, Laird NM and Rubin, DB (1977) Maximum likelihood from incomplete data via the EM algorithm. J Roy Stat Soc 39:1-38.

Embrapa: Empresa Brasileira de Pesquisa Agropecuária. (1999) Sistema Brasileiro de Classificação de Solos. EMBRAPA/ CNPSO, Rio de Janeiro, 412 pp.

Falconer DS and Mackay TFC (1996) Introduction to Quantitative Genetics. Longman, New York, 320 pp.

George PJ and Panikkar AON (2000) Rubber yielding plants. In: George PJ and Jacob CK (eds) Natural Rubber Agromanagement and Crop Processing Rubber. Institute of India, Kottayam, pp 20-28.

Gilbert N (1967) Additive combining abilities fitted to plant breeding data. Biometrics 23:45-49.

Gilbert NE, Dodds KS and Subramanian S (1973) Progress of breeding investigation with Hevea. V. Analysis of data from earlier crosses. J Rub Res Inst Mal 23:365-380.

Gonçalves P de S, Bortoletto N, Martins ALM, Costa RB and Gallo PB (2003) Genotype-environment interaction and phenotypic stability for girth growth and rubber yield of Hevea clones in São Paulo State, Brazil. Genet Mol Biol 26:441-448.

Gonçalves P de S, Martins ALM, Bortoletto N and Saes SA (2004) Selection and genetic gains for juvenile traits in progenies of Hevea in São Paulo State, Brazil. Genet Mol Biol 27:207-214.

Gonçalves P de S, Cardoso M, Santos ICI, Martins ALM, Ortolani AA and Colombo CA (1992) Selection of Hevea mother trees adapted to unpredictable annual climatic variability. Rev Bras Gen 15:137-147.

Gonçalves P de S, Furtado EL, Bataglia OC, Ortolani AA, May A and Belletti GO (1999) Genetics of anthracnose panel canker disease resistance and its relationship with yield and growth character in half-sib progenies of rubber tree (Hevea). Genet Mol Biol 22:583-589.

Gonçalves P de S, Martins ALM, Bortoletto N and Tanzini MR (1996) Estimates of genetic parameters and correlations of juvenile characters based on open pollinated progenies of Hevea. Braz J Gen 19:105-111.

Hernandez FBT, Lemos Filho MAF and Buzetti S (1995) Software HIDRISA e o Balanço Hídrico de Ilha Solteira. UNESP/FEIS/Área de Hidráulica e Irrigação, Ilha Solteira, Série Irrigação n. 1, 45 pp.

Ho CY (1979) Conservation and utilization of Hevea germoplasm. Malaysian Applied Biology 8:1-14.

IRSG: International Rubber Study Group (2004) Production of natural rubber. Wembley England. Rub Stat Bul 58:9-10.

Paiva JR de, Kageyama PY and Vencovsky R (1994a) Genetics of rubber tree Hevea brasiliensis (Willd. ex Adr. de Juss.) Müll. Arg., 2. Mating System. Silv Gen 43:373-376.

Paiva JR de, Kageyama PY, Vencovsky R and Contel EPB (1994b) Genetics of rubber tree Hevea brasiliensis (Willd. 
ex Adr. de Juss.) Müll. Arg., 1. Genetic variation in natural populations. Silv Gen 43:307-312.

Paiva JR de, Miranda Filho JB, Siqueira ER and Valois ACC (1982) Predição do ganho de alguns caracteres em seringueira em três esquemas de seleção. Pesquisa Agropecuária Brasileira 17:1646-1653.

Patterson HD and Thompson R (1971) Recovery of inter-block information when block sizes are unequal. Biometrika 58:545-554.

Priyadarshan PM (2003) Breeding Hevea brasiliensis for environmental constraints. Adv Agron 79:351-400.

Resende MDV (2002a) Genética Biométrica e Estatística no Melhoramento de Plantas Perenes. Embrapa Informação Tecnológica, Brasília, 975 pp.

Resende MDV (2002b) Software Selegen-Reml/Blup. Embrapa Florestas, Colombo, 67 pp (Documentos, 77).

Resende MDV and Fernandes JSC (1999) Procedimento BLUP individual para delineamentos experimentais aplicados ao melhoramento florestal. Rev Mat Estat 17:89-107.

Resende MDV and Higa AR (1994) Maximização da eficiência da seleção em testes de progênies de Eucalyptus através da utilização de todos os efeitos do modelo matemático. Bol Pesq Flor 28/29:37-55.

Resende MDV, Prates DF, Yamada CK and Jesus A (1996) Estimação de componentes de variância e predição de valo- res genéticos pelo método de máxima verossimilhança restrita (REML) e melhor predição linear não viciada (BLUP) em Pinus. Bol Pesq Flor 32/33:23-42.

Searle SR, Casella G and Mc Culloch CE (1992). Variance Components. J. Wiley, New York, 528 pp.

Simmonds NW (1989) Rubber breeding. In: Webster CC and Baulkwill WJ (eds) Rubber. Longman, New York, pp 85124.

Tan H (1987) Strategies in rubber tree breeding. In: Abbott AJ and Atkin RK (eds) Improving Vegetatively Propagated Crops. Academic Press, London, pp 28-63.

Thompson R (1973) The estimation of variance and covariance components when records are subject to culling. Biometrics 29:527-550.

Valois ACC, Pinheiro E, Conceição HEO and Silva MNC (1978) Competição de porta-enxertos de seringueira e estimativas de parâmetros genéticos. Pesq Agrop Bras 13:49-59.

Vencovsky R and Barriga P (1992) Genética Biométrica no Fitomelhoramento. SBG, Ribeirão Preto, 486 pp.

Vencovsky R and Crossa J (2003) Measurements of representativeness used in genetic resources conservation and plant breeding. Crop Sci 43:1912-1921.

Associate Editor: Márcio de Castro Silva Filho 